\title{
Testing the Effects of Simulated Climate Change Effects Using Open Sided Warming Chambers
}

\author{
JILL A. SHERWOOD $\uparrow$ DIANE M. DEBINSKI $\uparrow$ DEPARTMENT OF ECOLOGY, \\ EVOLUTION AND ORGANISMAL BIOLOGY $\uparrow$ IOWA STATE UNIVERSITY $\downarrow$ AMES
}

\author{
MATTHEW J. GERMINO $\uparrow$ DEPARTMENT OF BIOLOGICAL SCIENCES \\ IDAHO STATE UNIVERSITY $\downarrow$ POCATELLO \\ CURRENT AFFILIATION: USGS FOREST AND RANGE ECOSYSTEM SCIENCE CENTER $\downarrow$ BOISE
}

\section{$\uparrow$}

\section{AbSTRACT}

Regional models of global climate change for the northern Rocky Mountains predict warmer temperatures, and some of the main implications of these changes at a local level involve decreased snowpack, earlier snowmelt, and decreased soil moisture during the growing season. In order to mimic the anticipated effects of climate change, and test the responses from a soil microclimate and plant physiology perspective, open-sided warming chambers and snow removal treatments were applied to $2.44 \times 2.44 \mathrm{~m}$ plots in a sagebrush steppe meadow within Grand Teton National Park, WY. Four treatments included: (1) control, (2) reduced snowpack, (3) increased temperature, and (4) reduced snowpack with increased temperature. Snow was removed using shovels in early May, and chambers were placed at the same time. The chambers were left on the plots through mid-October. Soil moisture and temperature were measured and recorded at $5 \mathrm{~cm}$, and $25 \mathrm{~cm}$ depths using dataloggers set up at the time of snow removal and chamber placement. In addition, surface temperature was measured under each plot and within the study area. Plant physiological data on four plant species, including leaf temperature at dawn and mid-afternoon and water potential, were collected for all of the plots in July. Data are being analyzed to determine whether differences existed between the plots for soil moisture, soil and air temperature, and the plant physiological traits measured.

\section{$\uparrow \quad$ INTRODUCTION}

During the past century, temperature has increased by approximately $0.6^{\circ} \mathrm{C}$ (Walther et al. 2002). Estimated global temperature increases between $1.4^{\circ}-5.8^{\circ} \mathrm{C}$ are predicted during the period from 1990-2100 based on simulations from the Atmosphere-Ocean General Circulation Model (AOGCM) performed by the Intergovernmental Panel on Climate Change (IPCC) (Cubasch et al. 2001; Notaro et al. 2006). Future climate change predictions point to temperature increases, changes in precipitation, and the occurrence of increased extreme weather events (IPCC 2001; King 2005; Tebaldi et al. 2006). Climate changes are likely to be a major driver of ecological change. With these shifts, species will respond in different ways, resulting in dramatic implications for ecosystems. The responses of organisms, populations, and ecological communities are unlikely to be based on global averages to climate change. However, it is more likely that ecological communities will respond to local and regional climate variation and changes, which are spatially heterogeneous (Walther et al. 2002). Climate models predict that larger and more rapid changes in ecological communities will occur at higher altitudes and latitudes (Harte and Shaw 1995; Kim et al. 2002; Thuiller et al. 2005). When compared with $20^{\text {th }}$ century averages, the western United States had an average increase of $3^{\circ} \mathrm{C}$ during the period from $2003-2007$ (Saunders et al. 2008). 
Montane systems are some of the regions of the globe that may be most sensitive to climate change. Temperature increases will likely lead to a decrease in the duration of snow cover (IPCC 2001). Mote (2003) reported that springtime mountain snowpack showed widespread declines since 1950 at most locations, with largest declines at lower elevations, indicating temperature effects. The duration of the snow free period between 1972 and 2000 in the Northern Hemisphere has increased by five to six days per decade, while disappearance of spring snow cover has been three to five days earlier per decade (Dye 2002; Bjork and Molau 2007). Snowline is predicted to recede to higher elevations with changes in global and regional climates (Regonda and Rajagopalan 2004; Stewart et al. 2004; Lapp et al. 2005). It is likely that the impact of these changes will be significant throughout many ecosystems.

Snowpack volume is directly correlated with snowmelt date (Ostler et al. 1982; Price and Waser 1998). Shallow snowpacks melt earlier than heavy snowpacks and typically result in an earlier growing season (Price and Waser 1998; Arft et al. 1999; Inouye et al. 2002; Dunne et al. 2003). Plant phenologies are closely related to snowmelt timing and early season temperature regimes in montane systems (Billings and Bliss 1959; Fareed and Caldwell 1975; Galen and Stanton 1991; Kudo 1992; Walker et al. 1995; Inouye et al. 2002; Totland and Alatalo 2002; Dunne et al. 2003).

Snowpack characteristics can influence physical and ecological processes. Many montane systems are particularly dependent on the water that results from snowmelt (Harte et al. 1992), and they are often defined by strong hydrological gradients (Debinski et al. 1999). In the montane systems of the Greater Yellowstone Ecosystem, the majority of the annual precipitation falls as snow (Shaw 1958; Harte et al. 1992; Mote 2003). These montane systems contain a diverse plant community that attracts and supports a wide variety of species including insects, birds, and mammals (Swanson et al. 2007). Decreases in snowpack have been correlated with drier soils throughout the summer season, resulting in seasonal stress in plants (Ostler et al. 1982; Dunne et al. 2003). Plants are sensitive to changes in temperature and moisture and may be affected by shifts in moisture and temperature (Root et al. 2003; Roy et al. 2004). Harte and Shaw (1995) reported that experimental warming of plots in a montane system with dry soil conditions resulted in earlier forb production. Earlier plant production can expose the plants to detrimental conditions, including dieback from early frost.

Snow is important for thermal insulation, which is regulated by depth and density of the snow pack. Extreme temperatures are dampened at the soil surface directly under the snow, and many organisms rely on the insulating capacity of snow cover for heat retention (Billings 1959; Marchand 1987; Halfpenny and Ozanne 1989; Auerbach and Halfpenny 1991; Pomeroy and Brun 1999; Jones and Pomeroy 1999). Monson et al. (2006) reported that shallower snowpacks have less insulation potential, resulting in colder soil temperatures.

The objectives of this research were to simulate predicted climate changes in temperature and snowmelt using open-sided warming chambers and snow removal. Temperature and moisture, and plant physiological data were analyzed to determine the effects of the treatments. We expected that the passive heating would increase nighttime temperatures above the unheated plots. We also expected that snow removal would decrease the available soil moisture resulting in decreased water potential for the plants in the snow removal treatments. The data provides preliminary estimates of how these changes affect soil moisture and temperature, which will provide an initial assessment for future studies on the relationship between these parameters and plant phenologies.

\section{$\uparrow \quad$ METHODS}

\section{Plot set-up}

Three replicated blocks of four $2.44 \times 2.44$ $\mathrm{m}$ plots were placed in a relatively flat sagebrush meadow in Grand Teton National Park with the following treatments: snow removal (SR), passive heating $(\mathrm{H}+)$, snow removal and passive heating (SR and $\mathrm{H}+$ ) and control (CT). Each plot was separated by $5 \mathrm{~m}$ and laid out in a regular pattern of six by two plots within the meadow.

\section{Snow Removal and Open sided chamber set up}

Snow was removed manually using shovels on May 7, and placed at least $1 \mathrm{~m}$ from the plot. Snow varied in depth among plots, but on average, $\sim 20 \mathrm{~cm}$ was removed from each plot. Approximately $2 \mathrm{~cm}$ of snow was left on the plot to minimize soil disturbance and the possibility of vegetation damage. Snow was removed from an area approximated $0.5 \mathrm{~m}$ larger than the plot to minimize edge effects. Black 
plastic garden edging, approximately $10.5 \mathrm{~cm}$ high was placed around the perimeter of each plot to demarcate the location. Louvered open-sided chambers (OSC) were used for experimental warming of treatment of plots. The chambers were comprised of a wood frame with two sets of $1 / 8$ " Optix clear acrylic plexiglass louvered panels angled 50 degrees toward the center and placed approximately $2.5 \mathrm{~cm}$ apart (Figure 1). Two $2.44 \mathrm{x}$ $1.22 \mathrm{~m}$ frames were placed side by side to make up the $2.44 \times 2.44 \mathrm{~m}$ plots. The chambers were approximately $0.6 \mathrm{~m}$ high from the ground.

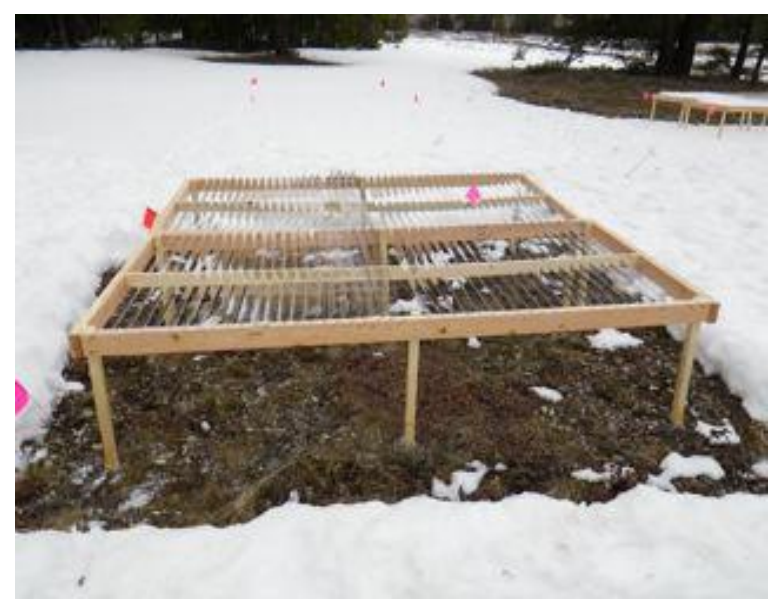

Figure 1.

\section{Temperature and soil moisture analyses}

Temperature and soil moisture (volumetric water content $\left(\mathrm{m}^{3} / \mathrm{m}^{3}\right)$ were measured and recorded at $5 \mathrm{~cm}$ and $25 \mathrm{~cm}$ depths using $5 \mathrm{TM}$ dielectric soil moisture sensors and EM50 dataloggers (Decagon Devices, Inc.) placed at the time of snow removal. Hand shovels were used to dig holes $25 \mathrm{~cm}$ in diameter to install dataloggers. Rocks and soil were carefully placed to the side so that they could be replaced as accurately as possible. Soil moisture sensors were placed with the probe oriented horizontally into the soil substrate with attempts to minimize the air gaps by placing packing soil tightly around the sensors due to rocky nature of soil in the area. Dataloggers recorded conditions every hour from mid-May through mid-October. In addition, radiation-shielded ECT temperature sensors (Decagon Devices, Inc.) were placed at a height of $25 \mathrm{~cm}$ in the middle of each plot to record air temperature.

\section{Vegetation water potential}

Four common perennial species of plants (Eriogonum umbellatum, Artemisia sp., Carex sp., and Balsamorhiza sagittata) were used to assess the water potential of the typical plant community in each plot. Samples were collected before dawn from

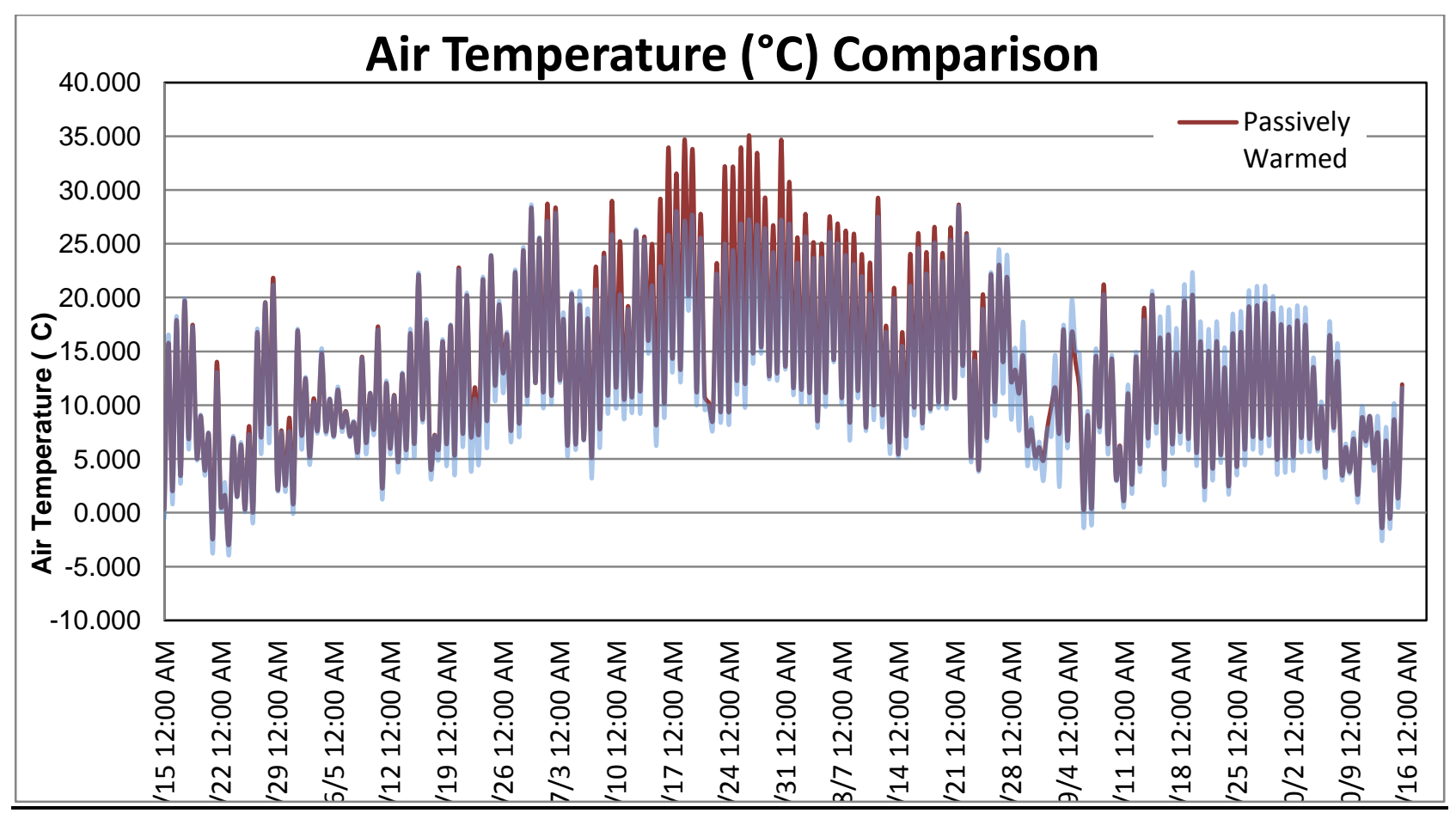

Figure 2. Comparison of air temperature $\left({ }^{\circ} \mathrm{C}\right)$ between the warmed and unwarmed treatments. 
each plot. Using a Scholander type pressure chamber (Plant Moisture Stress Instruments Co., Corvalis, OR), xylem pressure potentials of the plant tissues were measured almost immediately after collection to determine plant water potential.

\section{$\uparrow \quad$ PRELIMINARY ReSUlts}

Measurements of air temperature and soil temperature at $5 \mathrm{~cm}$ and $25 \mathrm{~cm}$ are shown in Figures 2 and 3. Statistical analyses are currently in progress.

\section{$\uparrow \quad$ CONCLUSIONS}

The preliminary results from this study support our predictions that the open-sided chambers would increase nighttime temperatures. This is consistent with similar studies and reveals that opensided chambers can simulate predicted climate change conditions.
We did not, however, see the expected trends for soil moisture or water potential from the snow removal treatments. Snow depth varied between plots with the average being only $20 \mathrm{~cm}$ of snow at the time of snow removal. Warm April temperatures resulted in snow melt occurring quickly. Although we were able to remove the snow at the beginning of May, snow depth was less than ideal for revealing the effects of snow removal. In addition, the warm temperatures melted the snow quickly after removal. Therefore, we were not likely to see the effects of snow removal because the amount removed was not large enough to affect soil moisture or plant water potential.

Temperature data from this preliminary study using open-sided warming chambers followed the expected trends. Even though snow removal did not follow the predicted trend, the results could have been altered by the early springtime warming. Further study using both the warming chambers and snow removal treatments over a greater period of time may provide important information about how these treatments affect the abiotic and biotic conditions under the treatments, thus providing important information about climate change.

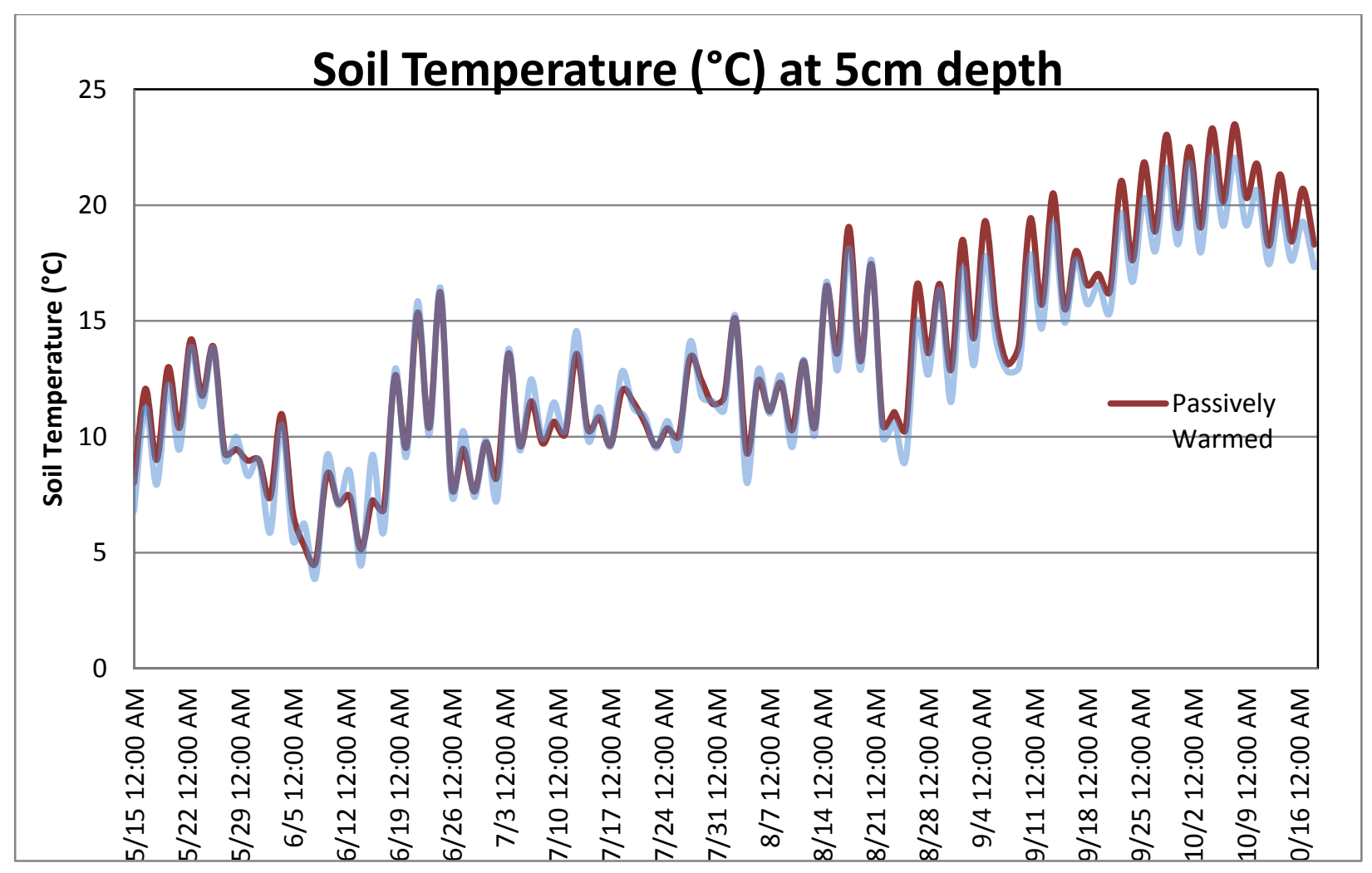

Figure 3. Comparison of soil temperature $\left({ }^{\circ} \mathrm{C}\right)$ at $5 \mathrm{~cm}$ depth between the warmed and unwarmed treatments. 


\section{ACKNOWLEDGEMENTS}

In addition to support from the UW-NPS Research Station, this project received key funding from The Center for Global and Regional Environmental Research (CGRER), Grant A. Harris Fellowship through Decagon Devices Inc., Joan Mosenthal DeWind Award through the Xerces Society, and Iowa State University Department of Ecology, Evolutionary, Organismal Biology. Design and coordination of the study has benefited from the assistance of Kelly McCloskey (Grand Teton National Park).

\section{$\downarrow$ Literature Cited}

Arft AM, Walker MD, Gurevitch J, Alatalo JM, BretHarte MS, Dale M, Diemer M, Gugerli F, Henry, GHR, Jones MH, Hollister RD, Jónsdóttir IS, Laine K, Lévesque E, Marion GM, Molau U, Molgaard P, Nordenhäll U, Raszhivin V, Robinson CH, Starr G, Stenström A, Stenström M, Totland $\mathrm{O}$, Turner PL, Walker LJ, Webber PJ, Welker, JM, Wookey PA. 1999. Responses of tundra plants to experimental warming: metaanalysis of the international tundra experiment. Ecological Monographs 69: 491-511.

Auerbach NA, Halfpenny JC. 1991. Snowpack and the Subnivean Environment for Different Aspects of an Open Meadow in Jackson Hole, Wyoming, U.S.A. Arctic and Alpine Research 23(1): 41-44.

Billings WD, Bliss LC. 1959. An alpine snowbank and its effects on vegetation, plant development, and productivity. Ecology. 40: 388-397.

Björk RG, Molau U. 2007. Ecology of alpine snowbeds and the impact of climate change. Arctic, Antarctic, and Alpine Research. 39:34-43.

Cubasch U and Coauthors. 2001. Projections of future climate change. Climate Change 2001: The Scientific Basis, J. T. Houghton et al., editors. Cambridge University Press. pp. 525-582.
Debinski DM, Jakubauskas ME, Kindscher K. 1999. A remote sensing and GIS-based model of habitats and biodiversity in the Greater Yellowstone Ecosystem. International Journal of Remote Sensing. 20:3281-3292.

Dunne JA, Harte J, Taylor KJ. 2003. Subalpine meadow flowering phenology responses to climate change: integrating experimental and gradient methods. Ecological Monographs. 73: 69-86.

Dye DG. 2002. Variability and trends in the annual snow-cover cycle in Northern Hemisphere land areas, 1972-2000. Hydrological Process 16: 3065-3077

Fareed M, Caldwel MM. 1975. Phenological patterns of two alpine tundra plant populations on Niwot Ridge, Colorado. Northwest Science 49:17-23.

Galen C, Stanton ML. 1991. Consequences of emergence phenology for reproductive success in Ranunculus adoneus (Ranunculaceae). American Journal of Botany. 78: 978-988.

Halfpenny JC, Ozanne RD. 1989. Winter: An Ecological Handbook. Boulder, Colo. Johnson Books. 273 pp

Harte J, Torn M, Jensen D. 1992. The Nature and Consequences of Indirect Linkages Between Climate Change and Biological Diversity. In: RL Peters and TE Lovejoy editors. Global Warming and Biological Diversity, (Yale Univ. Press, New Haven, CT, 1992), pp. $325-343$.

Harte J, Shaw R. 1995. Shifting dominance within a montane vegetation community: Results of a climate-warming experiment. Science. 267:876-880.

Jones HG, Pomeroy JW. 1999. The ecology of snowcovered systems: summary and relevance to Wolf Creek, Yukon. In: J. Pomeroy and R. Granger editors. Wolf Creek Research Basin: Hydrology, Ecology, Environment. National Water Research Institute. Minister of Environment: Saskatoon. 1-15. 
Inouye DW, Morales MA, Dodge GJ. 2002. Variation in timing and abundance of flowering by Delphinium barbeyi Huth (Ranunculaceae): the roles of snowpack, frost and La Niña, in the context of climate change. Oecologia 130:543-550.

IPCC, editors. 2001. Climate change 2001: synthesis report. A contribution of Working Groups I, II, and III to the Third Assessment Report of the Intergovernmental Panel on Climate Change. Cambridge University Press, Cambridge, UK.

Kim J, Kim TK, Arritt RW, Miller NL. 2002. Impacts of increased atmospheric $\mathrm{CO} 2$ on the hydroclimate of the western United States. Journal of Climate. 15:1926-1942.

King D. 2005. Climate change: the science and policy. Journal of Applied Ecology 42(5): 779-783.

Kudo G. 1992. Performance and phenology of alpine herbs along a snow-melting gradient. Ecological Research.7:297-304.

Lapp S, Byrne JM, Kienzle SW, Townshend I. 2005. Climate warming impacts on snowpack accumulation in an alpine watershed. International Journal of Climatology. 25(4): 521.

Marchand PJ. 1987. Life in the Cold: An Introduction to Winter Ecology. Hanover, N.H. University Press of New England. 176 pp.

Monson RK, Lipson DL, Burns SP, Turnipseed AA, Delany AC, Williams MW, Schmidt SK. 2006. Winter forest soil respiration controlled by climate and microbial community composition. Nature. 439:711714.

Mote PW. 2003. Trends in snow water equivalent in the Pacific Northwest and their climatic causes. Geophysical Research Letters. 30(12):3.1 - 3.4.

Notaro M, Liu Z, Williams JW. 2006. Observed vegetation climate feedbacks in the United States. Journal of Climate 19:763-786.

Ostler WK, Harper KT, McKnight KB, Anderson DC. 1982. The effects of increasing snowpack on a subalpine meadow in the Uinta Mountains,
Utah, U.S.A. Arctic and Alpine Research. $14: 203-214$.

Pomeroy JW, Brun E. 1999. Physical properties of snow. In: Jones HG, Pomeroy JW, Walker DA Hoham R. Editors. Snow Ecology. Cambridge University Press, Cambridge, UK

Price MV, Waser NM. 1998. Effects of experimental warming on plant reproductive phenology in a subalpine meadow. Ecology.79:1261-1271.

Regonda RK. Rajagopalan B. 2004. Seasonal Cycle Shifts in Hydroclimatology Over the Western United States. Journal of Climate. 18:372-384.

Root TL, Price JT, Hall KR, Schneider SH, Rosenweig C, Pounds JA. 2003. Fingerprints of global warming on wild animals and plants. Nature. 421:57-60.

Roy BA, Güsewell S, Harte J. 2004. Response of plant pathogens and herbivores to a warming experiment. Ecology. 85(9):2570-2581.

Saunders S, Montgomery C, Easley T, Spencer T. 2008. Hotter and drier: The west's changed climate. Rocky Mountain Climate Organization and the Natural Resources Defense Council, New York, 54 pp.

Shaw R.J. 1958.Vascular plants of Grand Teton National Park. American Midland Naturalist. 59:146-166.

Stewart IT, Cayan DR, Dettinger M.D. 2004. Changes in snowmelt runoff timing in western North America under a 'business as usual' climate change scenario. Climatic Change. 62:217-232.

Swanson FJ, Halpern CB, Cissell JH. 2007. Restoration of dry, montane meadows through prescribed fire, vegetation and fuels management: A program of research and adaptive management in western Oregon. Project 01C-3-3-10 Final Report to the Joint Fire Science Program. 29 September 2007.

Tebaldi C, Hayhoe K, Arblaster,JM, Meehl GA. 2006. Going to the extremes. Climatic Change 79: 185-211. 
Thuiller W, Lavorel S, Araujo MB, Sykes MT Prentice IC. 2005. Climate change threats to plant diversity in Europe. Proceedings of the National Academy of Sciences 102(23): $8245-8250$.

Totland O, Alatalo JM. 2002. Effects of temperature and date of snowmelt on growth, reproduction, and flowering phenology in the arctic/alpine herb, Ranunculus glacialis. Oecologia. 133:168-175.
Walker M, Ingersoll RC, Webber PJ. 1995. Effects of interannual climate variation on phenology and growth of two alpine forbs. Ecology: 76: 1067-1083.

Walther GR, Post E, Convey P, Menzel A, Parmesan C, Beebee TJC, Fromentin JM, HoeghGuldberg O, Bairlein J. 2002. Ecological responses to recent climate change. Nature 416:389-395. 